\title{
Biologists challenge museum shake-up plan
}

Cape Town. A task force set up by South Africa's minister for arts, culture, science and technology, Ben Ngubane, has set off a furore among biologists with a proposal that the country should have two national museums, one in each of its existing capital cities of Cape Town and Pretoria.

According to the proposal, made by the Arts and Culture Task Group (ACTAG), the two institutions will bring together ten of the present eighteen national museums. But only two of these are natural history museums: the South African Museum in Cape Town, the largest in the country, and the Transvaal Museum in Pretoria, which has the biggest collections.

As a result, the remaining three national museums with natural history collections the Natal Museum, the National Museum in Bloemfontein, and the Smith Institute of Ichthyology in Grahamstown - each stand to lose their national status and fall under provincial control.

The ACTAG recommendation has provoked substantial criticism, not least because none of the seven members of the task force's heritage subcommittee, responsible for providing guidance on museum policy, is a biologist, or has any experience of working in a natural history museum.

Ironically, the Smith Institute's collection of three-quarters of a million fish specimens makes it the only one of the five natural history museums which is truly national. The other four still reflect to varying degrees the regional bias of the former colonies in which they were set up, and which subsequently became provinces of South Africa under the old constitution.

Naas Rautenbach, Director of the Transvaal Museum, points out that the two new national museums being proposed are in the country's richest provinces, the Western Cape and Gauteng. The likely fate of museums in the remaining seven provinces is difficult to predict, he says, given other provincial priorities. Political leaders in some "appear to lack an understanding of the value of research and collections, although they do seem to appreciate the educational value of museums", he says.

Rautenbach adds that the decision does not augur well for South Africa's ability to fulfil a commitment made in the Rio Declaration of 1992 to draw up a complete inventory of the country's biodiversity before the end of the decade.

"Instead of going forward with this task, we run the risk of going backwards," he warns. Museums, as acknowledged repositories of specimens with known localities, are the major source of scientific information for most animal groups.

The task group's recommendation also assumes that the country will decide to maintain its existing dual capitals. But last month Patrick Lekota, premier of the Free State, threw a spanner in the works by offi-

the country.

Even given the problems of long-distance administration, many see this as a more workable solution. Furthermore, this would make it possible for the natural history museums to rationalize their collections either on a taxonomic or a regional basis.

The difficulty with both proposals is that they exclude several excellent museums, currently run by municipal or provincial authorities, from any rationalization at the national level. Yet the Durban Museum of Natural Science - the country's most popular museum - as well as the Port Elizabeth,

cially proposing that Bloemfontein, which is in the centre of the country, should become the national capital.

ACTAG rejected a suggestion that four national museums be formed out of all the existing eighteen museums which are currently national institutions. These would become museums of arts, culture, science and technology (including natural history) and military history respectively, each made up of a group of museums in cities around

Albany, East London, Kaffrarian and McGregor Museums, all have natural history collections of national value.

ACTAG appears to have completely ignored a third alternative, namely that all natural history museums be linked to the provinces in which they are located - as in Australia. Their financial future could be secured through earmarked funds provided to the provinces by the national government.

Michael Cherry

\section{Butterfly 'smugglers' take to the wing}

New Delhi. India is seeking the return of two German nationals who were caught at New Delhi airport last year while trying to smuggle 14,000 butterflies and moths out of the country. The Germans are being sought for trial under a domestic law which makes the smuggling of protected species a punishable offence.

The pair were stopped by customs officials on 14 August 1994. They had travelled to India as tourists, and had captured the insects from the Himalayas using local help - but without official permission.

Not all butterflies are protected in India. But the government's wildlife department had wanted to detain the Germans until all the insects in their collection were identified, in order to discover if any of them belonged to a special protected list.

But species identification is a time-consuming exercise. And the government anxious to avoid a diplomatic row - agreed to let the two Germans leave the country after their embassy in New Delhi had given a written guarantee that they would be brought back to India to stand trial if, at the end of species identification, they were found guilty.

The Calcutta-based Zoological Survey of India has now made detailed identification of 400 butterflies and 2,000 moths from the tourists' collection and found that they included four species from the protected list. Wildlife officials say that the pair have clearly violated the Wildlife Protection Act (1972), and should be put on trial.

A spokesman for the German embassy in New Delhi confirmed that it has received a note from the Indian Ministry of External Affairs, accusing the two tourists of violating the wildlife act and seeking their return to stand trial. He said that his embassy has asked the Indian government to provide it with "more details of the charges, in order to inform the concerned authorities back in Germany".

Friends of Butterflies, a Delhi-based nongovernmental organization, is worried that the delay in taking both the two German tourists and their local contacts to court may send the wrong signals to organizations that are engaged in the illegal multi-million dollar butterfly trade.

Virender Singh, the organization's coordinator, said that rare species of butterflies have been disappearing from the Himalayan states, as well as from the Andaman and the Nicobar islands in the Bay of Bengal. Many are ending up in so-called 'butterfly houses', making money through entrance fees charged to visitors to museums.

K. S. Jayaraman 